\title{
ANALYZING GEOLOGY TEXTBOOKS FOR SECONDARY SCHOOL CURRICULA IN GREECE AND SPAIN: EDUCATIONAL USE OF GEOLOGICAL HERITAGE
}

\author{
Meléndez G. ${ }^{1}$, Fermeli G. ${ }^{2}$, and Koutsouveli An. ${ }^{3}$ \\ ${ }^{1}$ Departamento de Geologia (Paleontologia) Universidad de Zaragoza, Pedro Cerbuna 12, 50009 \\ Zaragoza,Spain,gmelende@unizar.es \\ ${ }^{2}$ National and Kapodistrian University of Athens, Faculty of Geology and Geoenvironment, \\ Department of Hist. Geology - Paleontology, Panepistimiopolis, 15784 Zographou Athens, Greece, \\ gfermeli@geol.uoa.gr \\ ${ }^{3}$ Institute of Geology and Mineral exploration (IGME), Messogheion av. 70, 11527, Athens, \\ Greece,tessyk@igme.gr
}

\begin{abstract}
The teaching of geology as a separate discipline in secondary school curricula has been progressively reduced during the last 20 years in European countries. In the case of Greece and Spain, National Education laws have set geology as a supplementary matter of biology, geography and environmental sciences.

However, geology and Earth sciences are not subsidiary items of these "natural science" disciplines. This secondary role assigned to geology is creating serious concern among geologist community due to the substantial drop of geology contents in Secondary school curricula, which will presumably produce a consequent drop of geology students in universities and the lack of geologists in the society.

A proposal is made for using geological heritage as an educational tool and incorporating it to textbooks. This means using relevant points of geological and palaeontological heritage, as well as erosional features and fossil sites and relevant remains to illustrate natural processes and the History of Earth. This might provide a valuable instrument to create social and political concern for both Earth sciences and geological heritage, as well as to raise interest and enthusiasm in Secondary school students for the knowledge of Earth.
\end{abstract}

Key words: Secondary teaching, Earth sciences, Natural sciences, National Education laws.

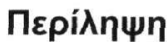

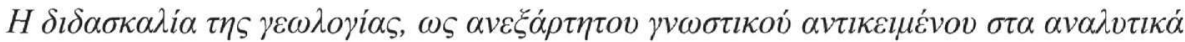

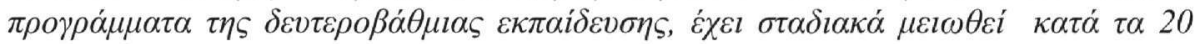

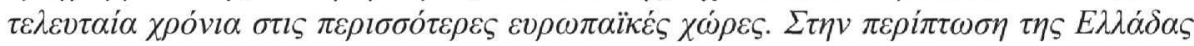

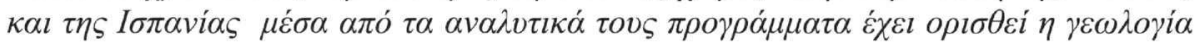

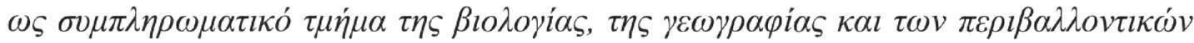
$\varepsilon \pi \imath \sigma \tau \eta \mu \omega ́ v$. 


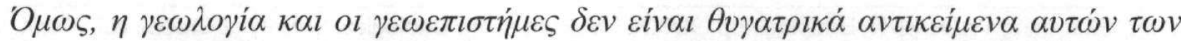

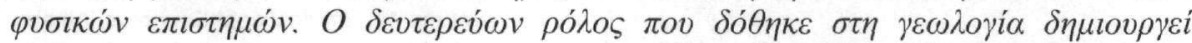

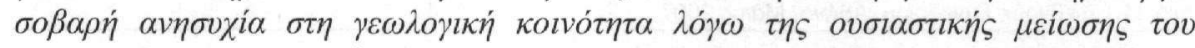

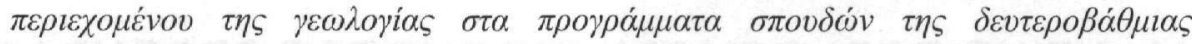

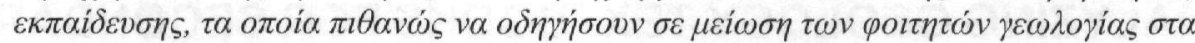

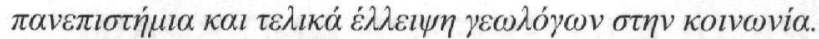

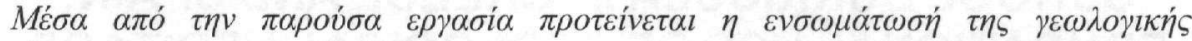

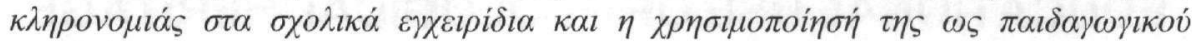

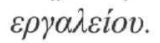

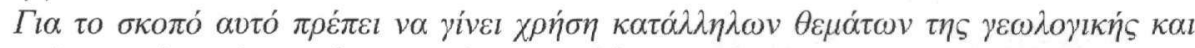

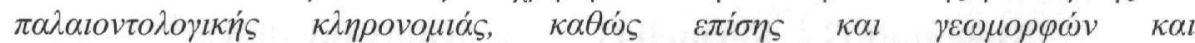

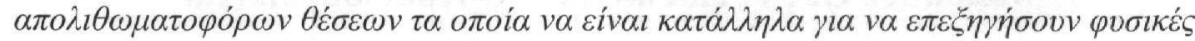

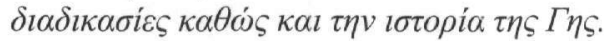

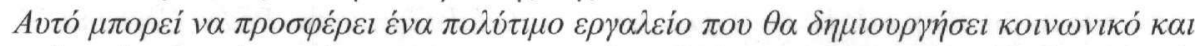

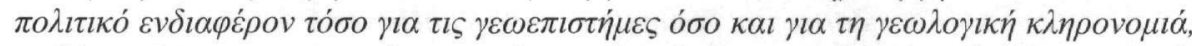

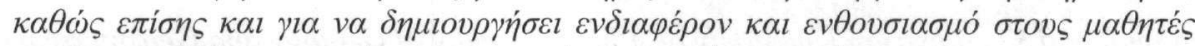

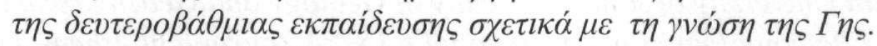

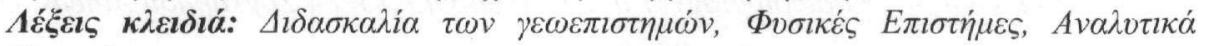

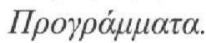

\section{Introduction}

The subject of Geology is not taught as an independent discipline in secondary schools in many European countries. Specifically, in Spain and Greece, Geology is taught in connection with other subjects: "Biology \& Geology" in Spain and "Geology \& Geography" in Greece (Meléndez et al. 2006a). Geology is no longer an independent topic/subject; although, young students are getting acquainted with geological subjects and have the background knowledge to apply and develop some geological concepts such as Geoenvironment in other school activities like "Environmental Education". Within the teaching contents of Geology, Palaeontology is assumed to be closely linked to Geology, as the fossil record is

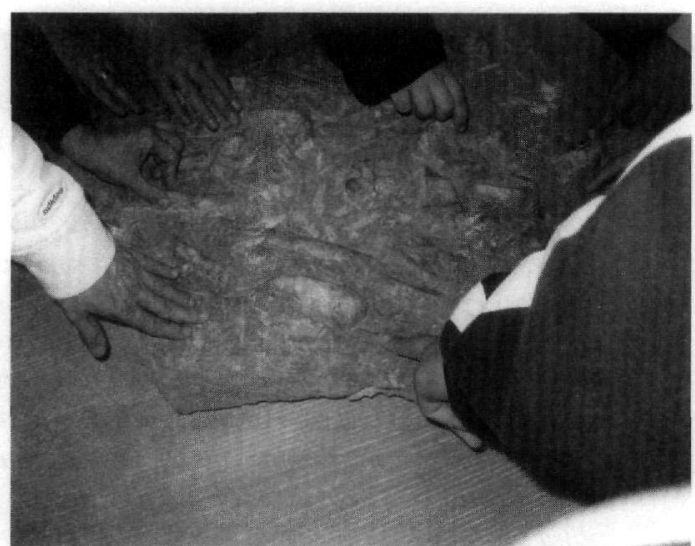

Figure 1 - Fossil specimens used as educational instruments, to illustrate geological and palaeontological problems generally associated to, or allocated within, the stratigraphical record, and palaeontological cases and fossil examples are most commonly used to illustrate both geological and evolutionary problems related with the history of Earth (Fig. 1).

Despite some small differences, Greek and Spanish educational systems display very similar parameters and age intervals (see table 1). A Pre-scholar interval starting at different age and lasting until 6 years; a Primary school interval lasting until 12 years and a Secondary school interval lasting until 18 years. Within it, a lower cycle encompassing 13 to 15 or 16 years old period, and an upper cycle, which ranges from 16 (Greece) or 17 (Spain) years old period until the access to University. Obligatory education period is also roughly similar in both countries, covering the Primary and the lower cycle of Secondary Education. 


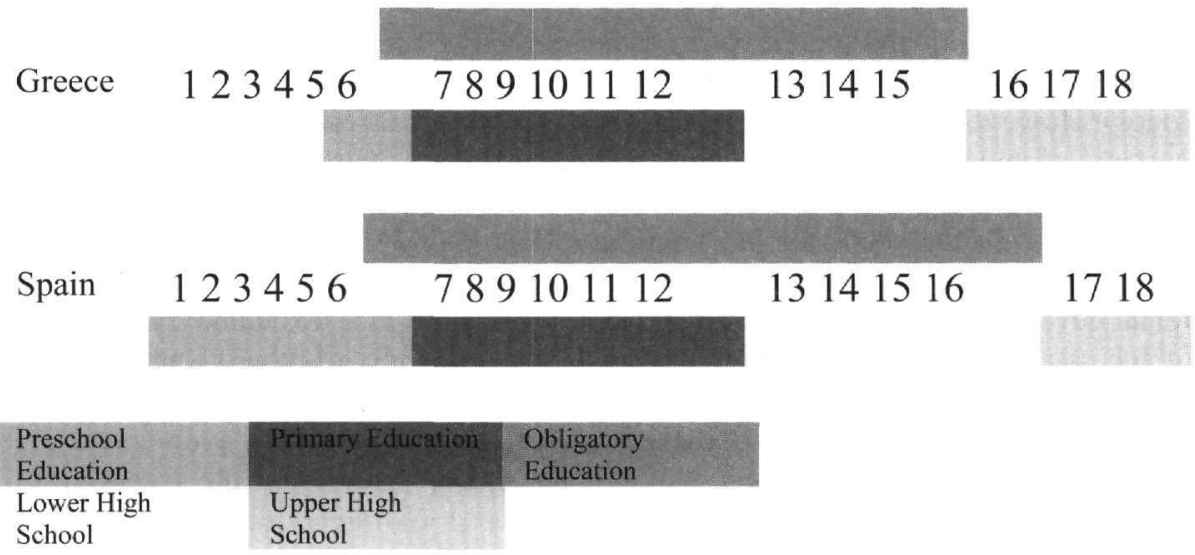

\section{The Spanish example}

\subsection{Historical}

Geology was established in the Secondary teaching in Spain, from the early fifties until 1972. Geology was taught in the upper cycle of the secondary school (15-17 years) as a part of a general subject: "Natural Sciences".

In 1971-72 a re-structuring of the upper cycle took place, now ranging from 15 to 18 years. A specific subject of Geology was set in the last year of the upper cycle (the University Orientation Year: C.O.U.) since 1978. This favoured the production of many new textbooks on Geology for this upper cycle. Until the early nineties, this subject was a part of the general access proofs to the University and hence, a high number of students followed the studies of Geology in the University. However, in the period 1993-96 since the approval and beginning of the new General Organic Law of the Educational System (LOGSE) Geology was set off from the University access selectivity proofs. The obvious consequence was that Geology, as an optional subject, was abandoned by most of students in the upper Secondary teaching cycle, involving a dramatic fall of number of students of Geology in the University.

At the present moment, a general subject "Biology and Geology" is taught in the last year of the lower cycle of secondary teaching; the so-called ESO (Obligatory Secondary teaching) comprising students from 12 to 16 years old. The purpose of presenting both disciplines under a one single curricular programme seems to be showing synthetically in a simple, accessible way to young students the mutual interaction between geosphere and biosphere under the point of view of a systemic approach (Fig. 2). However, the relative share of both subjects is distributed by law as $33 \%$ Geology and $67 \%$ Biology. This $33 \%$ of Geology is distributed as $81 \%$ Geology, $16 \%$ Palaeontology and $3 \%$ Palaeontological heritage. Geology still subsists as an isolated, optional subject in the last year of the upper cycle, from 16 to 18 year old students (López-Carrillo et al. in litt., Calonge et al. in litt.)

\subsection{The present-day situation}

However, in the last year, a new project of education Act has cast further threatens on Geology in Secondary teaching, as it will see the complete disappearance of Geology as a separate subject in the whole Secondary Education programmes; this will mean the disappearance "de facto" of Geology and Earth Sciences from the background of students and its remaining only as a minor part of other disciplines such as Biology or Environmental sciences. 
The public announcement of such new legal Act has immediately created great concern and raised strong reactions within the geological community in Spain, mainly from the Spanish Association for Earth Sciences teaching (AEPECT) as well as in the scientific societies, i.e. the Spanish Geological Society (SGE) and the Spanish Palaeontological Society (SEP). Official protests have been also raised from the Spanish Professional Association of Geologists (Ilustre Colegio oficial de Geólogos). However, it does not seem that these professional reactions have had any effect on the discussion of the new law in the high instances of the Ministry of Education or in the subsequent process of approval in the Parliament. The completion of such process, besides a complete ignorance of the needs for the teaching of Geology (and professional geologists) in the Society by the high educational authorities, would bring disastrous consequences for the professional development and existence of Geology itself. Once excluded from the selection proofs of access to the University and reduced to a small appendix of other "Natural Sciences", or "Environmental Sciences" curricula it is very unlikely that real geological knowledge can reach the new generations of Secondary School students. Furthermore, it will be even less probable that students should be attracted by a subject, which is not a "root matter" for the access proofs to the University. In fact in the current subject "Biology and Geology" the actual ratio between biological and geological contents is $67 \%$ (Biology) to $33 \%$ (Geology) hence making more difficult for the geological concepts to be properly developed (with such material space limitation), and sometimes the Geology chapters even to be reached and explained by teachers generally more familiar with Biology than with Geology (see Table 2). Leaving aside the last book analyzed (ECIR; Carrillo et al.), which corresponds to the subject "Geology" from the upper Secondary school cycle and in which all Didactical units correspond to Geology, the distribution of both chapters and pages corresponding to Geology very rarely reaches even $30 \%$ of the total. In the case of Palaeontology, the ratio is generally inferior to $10 \%$ of the total of Geology. This clearly appears below the numerical ratio that would correspond to Palaeontology within the Geological sciences.
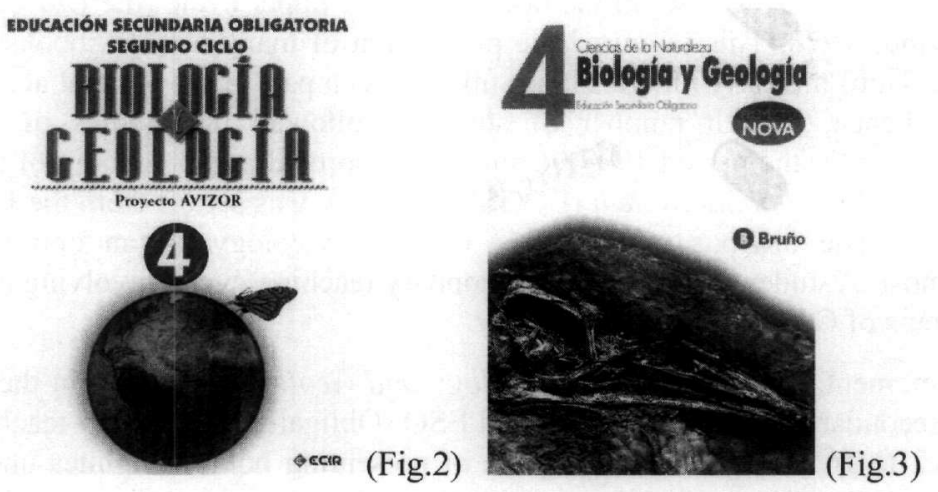

Figure 2 - The "Geosphere-Biosphere interaction" as represented in the cover of one $o$ one of the most widely used textbooks of the subject: "Biology and Geology" in the $4^{\text {th }}$ year of lower secondary teaching cycle (ESO)

Figure 3 - The palaeontological heritage presented as a valuable educational tool to show the History of life as enclosed within the Geological record, represented in the cover of another widely used textbook of the subject "Biology and Geology" ( $4^{\text {th }}$ year, ESO)

It seems obvious that such dramatic reduction of Geology in Secondary Teaching programmes, in time and development, as well as in importance, will mean the progressive reduction of Geology in Universities, beginning by students and followed by number of posts of lecturers and researchers, Departments of Geology and Faculties where Geology is currently actively taught. This predictable reduction of Geology in universities and in the Society, being progressively included within the so-called "Environmental Sciences", means the complete ignorance of the 
conceptual core of Geology itself. As explained below, although Earth sciences, including Geology and Palaeontology, display close conceptual links with biological sciences and, more secondarily, with Geography and social sciences, by means of physical geographical environments and human impact of geo and biosphere, all these disciplines have independent bodies of knowledge, separate fields of application (focusing on different problems) and distinct approaches and methodologies (see below, and Fig. 6).

\subsection{Geological heritage as educational tool}

Using the geological and palaeontological heritage as an educational tool in Secondary school textbooks has become a common educational strategy in the recent years since the establishment of Geology as a separate matter, in the late seventies. This is made through the illustration of particular geological cases or natural monuments, as well as special fossils, selected by their exceptional preservation, their rarity or degree of completeness, or by their evolutionary or social significance (Fig. 3). The obvious reason to select such special heritage valuable items is that they can illustrate better than any other some geological and palaeontological processes, as well as contribute to illustrate and resolve some geological or evolutionary problems better than theoretical diagrams, and provide a more accurate idea of the "real" Earth and of Evolution and history of life.

Table 2 - Relative ratios and distribution of contents of Biology and Geology in the textbooks of the subject "Biology and Geology" ( $4^{\text {th }}$ year of ESO; first eight books listed) and of the subject "Geology" from the second year of upper Secondary School $\left(2{ }^{\text {nd }}\right.$ year Bachillerato:

Carrillo et al.) from the main Editorials in Spain. Key to quantified parameters: DU: Number of didactical units; GEOL: Geology, PAL: Palaeontology, CONT: Contents, PAG: $\mathrm{N}^{0}$ of pages, INT: Corresponding interval;

\begin{tabular}{|c|c|c|c|c|c|c|}
\hline \multirow[t]{2}{*}{ Editorial } & \multirow[t]{2}{*}{ Year } & \multirow[t]{2}{*}{ Authors } & \multicolumn{2}{|c|}{$\begin{array}{c}\text { DU. } \\
\text { GEOL.CONT. }\end{array}$} & \multirow{2}{*}{$\begin{array}{l}\text { DU. PAL } \\
\text { CONT. } \\
\text { NOU.D. }\end{array}$} & \multirow[b]{2}{*}{ PÁG./INT. } \\
\hline & & & $\mathrm{N}^{0} \mathrm{DU}$. & PÁG./INT. & & \\
\hline SM & 1998 & Alcalde et al. & 4 & $62 / 3$ & 1 & $18(2)$ \\
\hline ECIR & 1997 & $\mathrm{G}^{\mathrm{a}}$ Gregorio et al. & 2 & $58 / 3$ & 2 & $7 / 1$ \\
\hline ANAYA & 1998 & Berges et al. & 3 & $62 / 3(0,26)$ & 2 & 12 \\
\hline VICENS VIVES & 1999 & Fdez et al. & $4(0,36)$ & $62 / 3(0,28)$ & 2 & $41 / 3(0,18)$ \\
\hline BRUÑO & 1999 & Panadero et al & 2 & $64 / 3$ & 2 & $8 / 1$ \\
\hline EDEBE & 1999 & R.Calafell et al. & 2 & $44 / 3$ & 1 & $6 / 1$ \\
\hline MC GR. HILL & 1998 & Calvo et al.. & 3 & $50 / 3$ & 2 & $8 / 1$ \\
\hline EDELVIVES & 1999 & España et al. & 3 & $82 / 3$ & 1 & $37 / 2$ \\
\hline ECIR/Geol & 2001 & Carrillo et al. & $11(1,0)$ & $328 / 3(1,0)$ & $1(0,92)$ & $28 / 2(0,085)$ \\
\hline
\end{tabular}

The use of geological and palaeontological heritage items as educational instruments and strategies has undergone a significant increase parallel to the progressive systematisation of heritage itself in the recent years (Delvene et al. 2006, Meléndez et al. (eds), 1999, Meléndez and Peñalver (eds) 2002, Meléndez et al. 2006 b, c). As shown in Table 3 the use of Geological and Palaeontological heritage in textbooks of Secondary school displays wide variations.

However, some regularities may be observed: On what concerns the mention to heritage, this, with very few exceptions, is usually always implicit, i.e. prominent heritage features are used as relevant cases to illustrate problems or processes but they are not mentioned as protected or declared sites or fossil items. Concerning the illustrations, from the generally many illustrations included in text, those representing heritage valuable sites or items very rarely reach $40 \%$ of the total. From these "heritage illustrations", those representing Spanish cases are a minimum 
proportion of the total and in some case the ratio descends to $0 \%$. This means that well-known international heritage cases, rather than local examples, are preferred by authors to illustrate problems. As regards the terminological level at which the heritage is employed, it corresponds in all cases to the first level, i.e. heritage cases are used or briefly mentioned, but neither are they remarked as protected or legally defined (level 2) nor a mention is made to the heritage laws or regulations in the Country.

Table 3 - Quantified estimation of the treatment given to Geological and Palaeontological Heritage in textbooks. Cont: Contents, NO/IMPL/EXPL designate respectively: No mention to Heritage; Implicit mention (=Geol heritage used although not explicitly mentioned), and

Explicit mention to Heritage, ILLUST: Illustrations used: IT: Total number, IGH/IPH:

Number of Illustrations of Geological/Palaeontological Heritage; INGH/INPH:

Corresponding index (=percentage of total illustrations subdivided by 100); INGHE/INPHE:

Corresponding values of Heritage Index counting the illustrations referred to Spanish

heritage cases. TERM: Terminological level at which Heritage is treated in the text

\begin{tabular}{|c|c|c|c|c|c|c|c|c|c|c|c|c|c|c|c|}
\hline \multirow[t]{2}{*}{ Editorial } & \multicolumn{3}{|c|}{$\begin{array}{l}\text { Geol.Herit } \\
\text { Cont. }\end{array}$} & \multicolumn{3}{|c|}{$\begin{array}{c}\text { Pal.Herit } \\
\text { Cont. }\end{array}$} & \multicolumn{2}{|c|}{$\begin{array}{c}\text { Geol. } \\
\text { Herit } \\
\text { Ilustr. }\end{array}$} & \multirow[b]{2}{*}{ INGH } & \multirow[b]{2}{*}{ INGHE } & \multicolumn{2}{|r|}{$\begin{array}{c}\text { Pal. } \\
\text { Herit } \\
\text { Ilustr. }\end{array}$} & \multirow[b]{2}{*}{ INPH } & \multirow[b]{2}{*}{ INPHE } & \multirow{2}{*}{$\begin{array}{l}\text { TERM } \\
(1-3) \\
\end{array}$} \\
\hline & NO & IMPL & EXPL & NO & IMPL & EXPL & IT & $\mathrm{IGH}$ & & & IT & $\mathrm{IPH}$ & & & \\
\hline SM & & $\mathrm{x}$ & & & $x$ & & 41 & 21 & 0,51 & 0,24 & 32 & 13 & 0,41 & 0,16 & 1 \\
\hline ECIR & & $\mathrm{x}$ & & & $\mathrm{x}$ & & 57 & 18 & 0,31 & 0,17 & 20 & 10 & 0,5 & 0,05 & 1 \\
\hline ANAYA & & $\mathrm{X}$ & $(\mathrm{X})$ & & $\mathrm{X}$ & & 120 & 14 & 0,12 & 0,1 & 22 & 4 & 0,18 & 0,09 & 1 \\
\hline $\begin{array}{l}\text { VICENS } \\
\text { VIVES } \\
\end{array}$ & & $\mathrm{X}$ & & & $\mathrm{X}$ & $(\mathrm{X})$ & 91 & 13 & 0,14 & 0,13 & 62 & 12 & 0,19 & 0,06 & 1 \\
\hline BRUÑO & & $\mathrm{X}$ & & & $\mathrm{X}$ & & 57 & 10 & 0,17 & 0,1 & 17 & 6 & 0,35 & 0,17 & 1 \\
\hline EDEBE & & $\mathrm{X}$ & & & $\mathrm{X}$ & & 54 & 3 & 0,05 & 0 & 10 & 1 & 0,1 & 0 & 1 \\
\hline $\begin{array}{c}\text { MC GR. } \\
\text { HILL }\end{array}$ & & $\mathrm{x}$ & & & $\mathrm{X}$ & & 52 & 13 & 0,25 & 0,19 & 24 & 6 & 0,25 & 0,12 & 1 \\
\hline EDELVIVES & & $\mathrm{x}$ & & & $\mathrm{X}$ & & 96 & 15 & 1,15 & 0,031 & 45 & 1 & 0,02 & 0 & 1 \\
\hline ECIR/Geol & & $\mathrm{X}$ & & & $\mathrm{X}$ & & 552 & 148 & 0,27 & & 51 & 18 & 0,35 & 0,032 & 1 \\
\hline
\end{tabular}

\section{The Greek example}

\subsection{A brief presentation of the Geology subject in Greek educational system}

\subsubsection{From 1932 to 2000}

Geology was taught in Greece for the first time, during the school year 1932-33, as a part of a subject called "Natural History". A second effort took place during 1941-42, Geology being again a part of the same subject. In 1961 Geology was re-included in all Secondary School programmes as a "clear Geology" subject, remaining more or less unchanged for eighteen years, with only some minor changes in its content. In the year 1979-80, the "Geology" programmes were enlarged, including more specific aims and goals.

In 1997 the subject Geology was suppressed from high schools teaching programmes, and so this was the most negative year for the geological education in Greece. From 1997 until 2001 geological issues were mostly included (hidden) in such subject as "Geography" in the first stage (Gymnasium): students from 12 to 15 years old; "Issues of Environmental studies" and the "Natural resources management" in the second stage (Lyceum): students from 16 to 18 years old (Table 4).

The analysis of Geography text books in $1^{\text {st }}$ and $2^{\text {nd }}$ Grade of lower High school, shows that from 97 lessons (48 lessons in $1^{\text {st }}$ and 49 in $2^{\text {nd }}$ Grade) totally included in these only 4 are of purely geological content ( 2 in $1^{\text {st }}$ Grade, and 2 in $2^{\text {nd }}$ Grade), 20 cover some geological elements ( 12 in $1^{\text {st }}$ Grade, 8 in $2^{\text {nd }}$ Grade), whereas 55 (29 in $1^{\text {st }}$ Grade, 19 in $2^{\text {nd }}$ Grade) could comprise elements of geosciences (Fermeli 2004, Fermeli and Marcopoulou-Diacantoni 2004). 
This means that the relative share of Geography to Geology is $96 / 4 \%$ in both grades of the lower High School (Fig. 4). However, if chapters including words, phrases or pictures related to Geology are counted, then the presence of Geology increases to $25 \%$ in the $1^{\text {st }}$ and to $16 \%$ in $2^{\text {nd }}$ grade.

No direct mention to Geological heritage or relative terms is made in the Geography curriculum. However, some classical examples, such as the Corinth channel, Thermopiles passage in $1^{\text {st }}$ grade and Mount Athos and Santorini volcano presented in Geography books in $2^{\text {nd }}$ grade constitute clear components of it.

\subsubsection{The present situation (From 2001 to present) - A new curriculum}

Educational systems evolve dynamically and must reflect the changes in the Society. During 20012003, the Greek Pedagogical Institute in order to reconstruct obligatory education (Primary and lower High school) applied a long-term educational planning strategy, which has been expanded further so as to apply to nursery school too.

Table 4 - Distribution of teaching hours of Natural sciences in Lower High School. Numbers referred correspond to weekly teaching hours on an annual basis

\begin{tabular}{|c|c|c|c|c|c|c|c|c|c|c|c|c|c|c|c|c|}
\hline \multicolumn{17}{|c|}{ Lower High School (Gymnasium) /(12 to 15 years old $)$} \\
\hline \multicolumn{3}{|c|}{ Grade } & \multicolumn{3}{|c|}{ Biology } & \multicolumn{5}{|c|}{$\begin{array}{l}\text { (Geology-) } \\
\text { Geography }\end{array}$} & \multicolumn{4}{|c|}{ Physics } & \multicolumn{2}{|c|}{ Chemistry } \\
\hline \multicolumn{3}{|c|}{ A } & \multicolumn{3}{|c|}{2} & \multicolumn{5}{|c|}{2} & \multicolumn{4}{|c|}{-} & \multicolumn{2}{|c|}{-} \\
\hline \multicolumn{3}{|c|}{ B } & \multicolumn{3}{|c|}{-} & \multicolumn{5}{|c|}{2} & \multicolumn{4}{|c|}{2} & \multicolumn{2}{|c|}{1} \\
\hline \multicolumn{3}{|c|}{$\mathrm{C}$} & \multicolumn{3}{|c|}{2} & \multicolumn{5}{|c|}{-} & \multicolumn{4}{|c|}{2} & \multicolumn{2}{|c|}{1} \\
\hline \multicolumn{3}{|c|}{ Total } & \multicolumn{3}{|c|}{4} & \multicolumn{5}{|c|}{4} & \multicolumn{4}{|c|}{4} & \multicolumn{2}{|c|}{2} \\
\hline \multicolumn{17}{|c|}{ Upper High School (Lyceum) /(16 to 18 years old) } \\
\hline & \multicolumn{4}{|c|}{ Biology } & Geology & \multicolumn{4}{|c|}{ Physics } & \multicolumn{5}{|c|}{ Chemistry } & \multicolumn{2}{|c|}{$\begin{array}{l}\text { OTHER RELATIVE OPTIONAL } \\
\text { COURSES }\end{array}$} \\
\hline Grade & G & $\mathrm{S}$ & $\mathrm{Tl}$ & $\mathrm{O}$ & & G & $\mathrm{S}$ & $\mathrm{T} 1$ & $\begin{array}{l}\mathrm{T} \\
2\end{array}$ & G & $\mathrm{S}$ & $\mathrm{Tl}$ & $\mathrm{T} 2$ & 0 & NRM & IES \\
\hline A & - & & & & - & $2 / 3$ & & & & 2 & & & & & & \\
\hline B & 1 & & & 2 & - & 2 & 2 & 2 & & 1 & 2 & - & & 2 & 2 & 2 \\
\hline $\mathrm{C}$ & 1 & 2 & & & - & 1 & 3 & $2^{*}$ & 3 & - & 2 & $3 * *$ & & & & \\
\hline Total & 2 & 2 & & 2 & 0 & $5 / 6$ & 5 & 4 & 3 & 3 & 4 & 3 & & 2 & 2 & 2 \\
\hline TOTAL & \multicolumn{4}{|c|}{6} & 0 & \multicolumn{4}{|c|}{$17 / 18$} & & & 12 & & & 2 & 2 \\
\hline In total & & 3 & 100 & & atural & 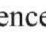 & & 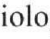 & 6 , & 1 & 0 & Phys & 18, & $\mathrm{Ch}$ & istry & \\
\hline $\begin{array}{l}\text { Legend } \\
\text { G: Gene } \\
\text { S: Divis } \\
\text { T1: Tec } \\
\text { T2: Tec } \\
\text { and ser } \\
\text { school. }\end{array}$ & $\begin{array}{l}\text { Ed } \\
\text { sci } \\
\text { olog } \\
\text { olog } \\
\text { s)/ } \\
\text { Opt }\end{array}$ & $\begin{array}{l}\text { ation } \\
\text { ces } \\
\text { l di } \\
\text { l di } \\
\text { ly in } \\
\text { hal c }\end{array}$ & $\begin{array}{l}\text { cour } \\
\text { ision } \\
\text { ision } \\
\text { the } 3 \\
\text { urse }\end{array}$ & (fiel & $\begin{array}{l}\text { f Comp } \\
\text { of Upp }\end{array}$ & $\begin{array}{l}\text { scie } \\
\text { High }\end{array}$ & aces & & $\begin{array}{l}* \text { I } \\
\text { per } \\
* * C \\
2 \text { ho } \\
\text { NRI } \\
\text { (NR } \\
\text { IES= }\end{array}$ & $\begin{array}{l}\text { addi } \\
\text { ek. } \\
\text { emis } \\
\text { s pe } \\
=\text { NA } \\
\text { ISSL }\end{array}$ & $\begin{array}{l}\text { on th } \\
\text { (1 } \\
\text { veek } \\
\text { S O }\end{array}$ & $\begin{array}{l}\text { re is t } \\
\text { lour p } \\
=3 \mathrm{~h} \\
\mathrm{~L} \text { RE } \\
\text { ENV }\end{array}$ & $\begin{array}{l}\text { cour } \\
\text { week } \\
\text { rs pe } \\
\text { URC } \\
\text { ONN }\end{array}$ & $\begin{array}{l}\text { "I } \\
\text { as } \\
\text { we } \\
\text { ES } \\
\text { EN" }\end{array}$ & $\begin{array}{l}\text { ctrolo } \\
\text { ANAC as } \\
\text { L ST }\end{array}$ & $\begin{array}{l}\text { hours } \\
\text { emistry } \\
\text { NT } \\
\text { S }\end{array}$ \\
\hline
\end{tabular}

The Greek educational system has been founded on the basis of nine-year-long obligatory education (6-15 years, see Table 1). For this reason, permanent structure and effective function of the system are not only matters of lower High School, but also constitute preconditions of upgrading upper High School, Secondary Technical and vocational institutions. 
In this context, obligatory education is the determining factor for the development of students' personality, citizenship awareness and positive attitude towards life-long learning (GP: 1366/v.B'/18-10-2001, $\left.1375 / v \cdot B^{\prime} / 18-10-2001\right)$.

In the present curriculum, traditional school subjects are maintained but their content is organized around disciplinary and cross-disciplinary concepts in two axes: a vertical (integral) and a horizontal (cross-thematic) axe. The final aim of this distribution is to achieve school knowledge cohesion at the most. A special emphasis is also put on processes able to transform academic knowledge into school knowledge as well as on the values and attitudes associated with academic learning and thinking (Fermeli and Koutsouveli, in litt.).

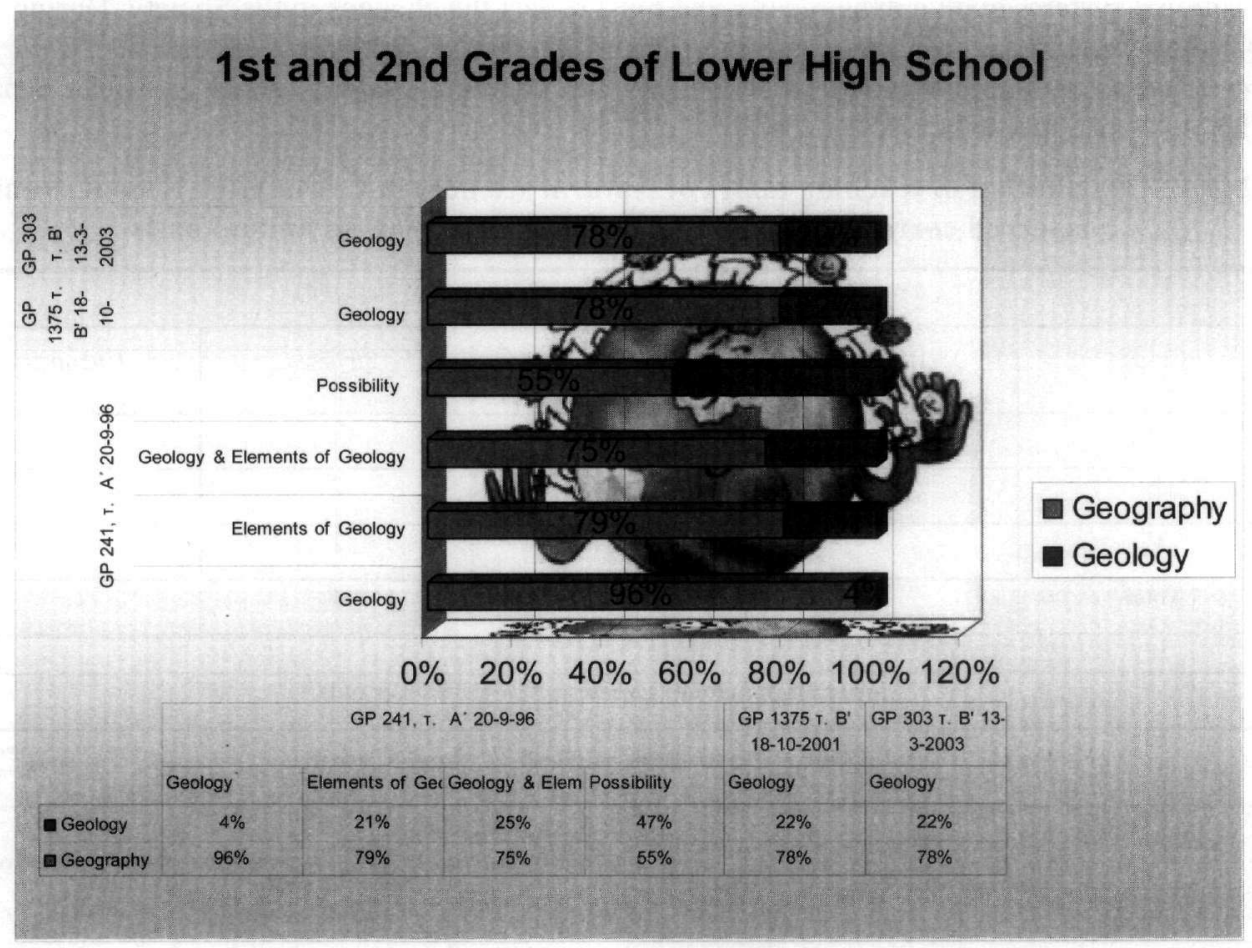

Figure 4 - Geology, geological elements and the possibility of introduction of geological elements in the curriculum of "Geology-Geography" in the lower High School $\left(1^{\text {st }}\right.$ and $2^{\text {nd }}$ Grades)

\subsection{Aspects of the new Curriculum}

\subsubsection{Integral curriculum}

In this new curriculum, the subject Geology is allocated within the Geography programme being now called Geology-Geography. New textbooks are expected to appear in 2007.

Generally, we can say that the philosophy and the content of the preview's curriculum however remain in this curriculum. In fact, there is a considerable increase of the teaching hours on geological subjects. Specifically, in the $1^{\text {st }}$ grade they increase from 5 to 15 hours, composing a total of 48 hours per year, and in the $2^{\text {nd }}$ grade they increase from 2 to 5 hours, composing a total of 49 hours per year (Table 5). In other words there is a share of $33 \%$ of Geology, which will be proposed in the integral-curriculum for $1^{\text {st }}$ Grade and a $10 \%$ in second grade of the High school (Fig. 4) (GP: 304/v.B'/13-03-2003). This change has greatly enhanced the geological education in Greece. 
Table 5 - Comparison of features/elements of geological content of curriculum of "Geography" to that of "Geology-Geography"

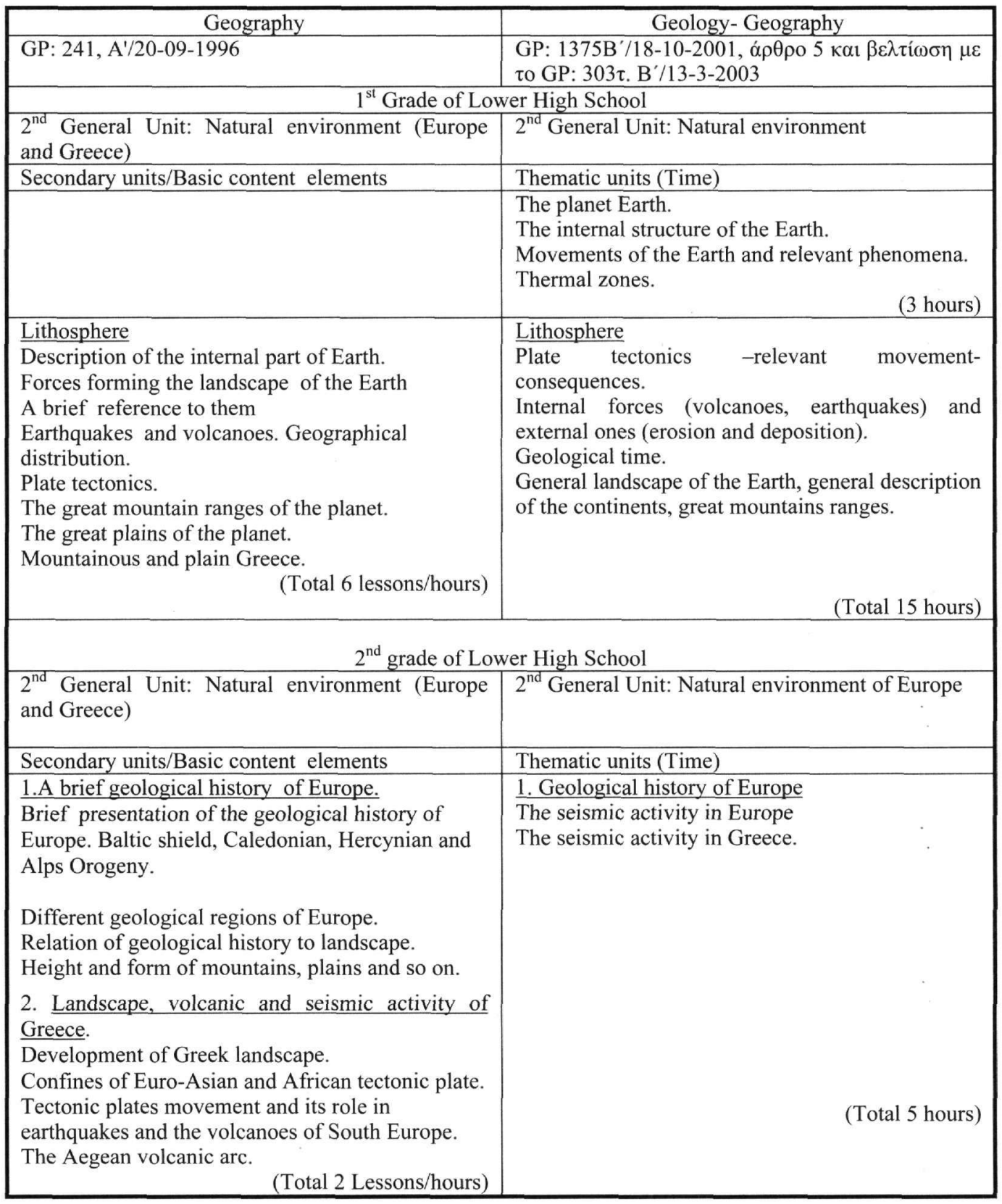

\subsubsection{Cross-thematic curriculum}

It includes the guiding principles contents and cross-thematic key words. The Geology-Geography cross-thematic curriculum is structured into four units in both grades: (a) Location-Geographical positioning (b) Means of recording and representing geographical features (c) Natural environment (d) Man-made environment. The geological cross-thematic content guiding principles are included in the unit "natural environment" (GP: 1196/v. B'/26-8-2003) (See Table 6). 
The distribution of the cross-thematic geological issues in the textbooks is supported by crosscurricular key words (concepts), which constitute the main rings for the horizontal connection of the different disciplines. According to the Geology-Geography cross-thematic curriculum the following key words are proposed: Space, Time, System, Interdependence, Interaction and Change (Table 6).

\subsection{Discussion}

In the recent Greek curriculum, Geology is proposed to be a part of a lesson under the title "Geology-Geography", 2 hours per week in $1^{\text {st }}$ and $2^{\text {nd }}$ Grade of Lower High School. Although Geological heritage is not directly mentioned in the content, it is nevertheless implied in geological aspects.

In this curriculum, emphasis is put on processes able to transform academic knowledge into school knowledge as well as on the values and attitudes associated to academic learning and thinking. Learning process is approached in a holistic manner, by promoting cross-disciplinary connections and relationships.

Table 6 - Cross-thematic curriculum, unit Natural environment (Geological issues and crossthematic key-words)

\begin{tabular}{|c|c|}
\hline $1^{\text {st }}$ Grade of Lower High School & $2^{\text {nd }}$ Grade of Lower High School \\
\hline $\begin{array}{l}\text { Natural environment } \\
\text { Lithosphere: } \\
\text { - Internal structure of the Earth. } \\
\text { - } \quad \text { Continental drift and plate tectonics. } \\
\text { - Internal forces and their results } \\
\text { (volcanoes, earthquakes). } \\
\text { - External forces (erosion, deposition). } \\
\text { - Geological time. }\end{array}$ & $\begin{array}{l}\text { Natural environment } \\
\text { - } \quad \text { Geological aeons. } \\
\text { A brief geological history and tectonic } \\
\text { areas of Europe and Greece. } \\
\text { - Internal forces-Volcanoes and seismic } \\
\text { activity in Europe and Greece. } \\
\text { - Landscape and phytogeographical areas } \\
\text { of Europe and Greece. } \\
\text { - Seas and coasts of Europe and Greece. } \\
\text { - The Mediterranean Sea. } \\
\text { - Geographical distribution of climatic } \\
\text { types in Europe and Greece. } \\
\text { - } \quad \text { Rivers and lakes in Europe and Greece. } \\
\text { Greece. } \\
\text { Cross-curriculum Key-words: Space, Time, } \\
\text { System, Interdependence, Interaction, } \\
\text { Change. }\end{array}$ \\
\hline
\end{tabular}

This is a challenge for geoscientists to illustrate an attractive way to transform the scientific knowledge and methodology into school knowledge in order to make geology comprehensive and attractive for the students.

Geological heritage offers a good opportunity:

- As a pedagogical tool. There are geological "sites" in every region, even in urban areas. On the condition that these sites fulfil the suitable criteria (selection of geosites), they can be pedagogical geosites by means of which, we can teach geology to students.

- As a cross-thematic concept through the key-word "heritage". Geosites have a multidiscipline value and are connected with other sciences like archaeology, biology, history, ecology etc., as the specific values that they hold are clearly projected on archaeological, historical, ecological and cultural contents (Fig. 5). 
This way, geological heritage could be a basic/fundamental parameter on which we could develop our methodological tools to teach Geology in schools.

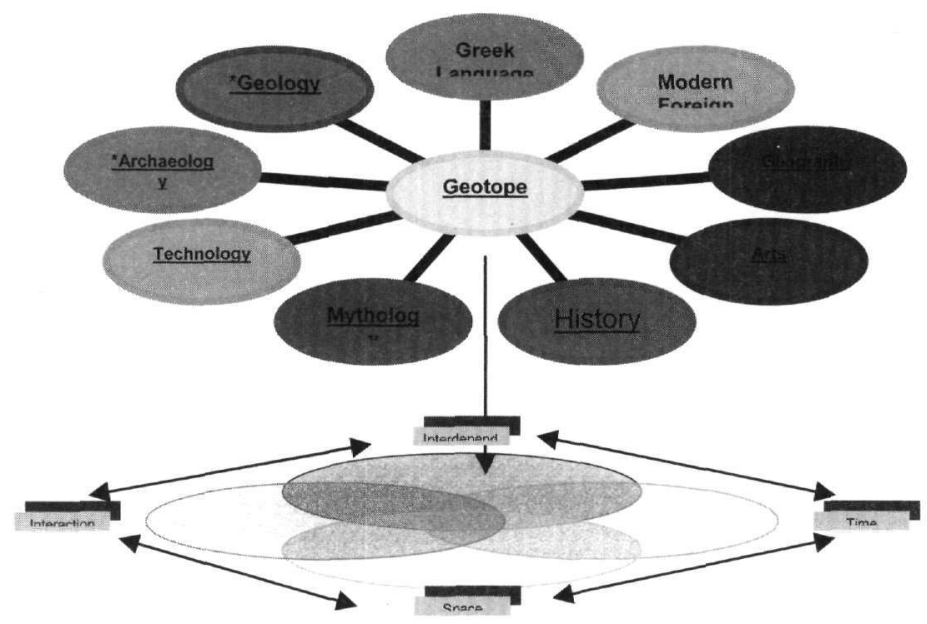

Disciplines:Geography, Biology, Greek Language, Modern Foreign Languages, Archaeology, History, Mythology, Technology, Arts. Cross-curricular Key-words:Interdependence, Space, Time, Interaction

\section{Figure 5 - Cross-curriculum / thematic approach of Geological Heritage (Fermeli 2004)}

All the above, can help pupils to obtain a more comprehensive view of the world, using their skills and knowledge.

\section{Comparison}

\subsection{Similarities and differences}

In both educational systems, Greece and Spain, Geology appear to be regarded as a scientific discipline closely related to other natural or social branches of knowledge, to the point that it can be taught jointly with them in a unique subject. Such decision may be justified by social, political or educational reasons. However, it would appear clear that such mixed curriculum should maintain a sharp equitability in development, time of dedication, number of didactical units and extension (i.e. number of pages, illustrations...) within textbooks. In the case of Greece, despite the curricular association of Geology with such social science as Geography, it seems that both extension, time of development and conceptual links between both disciplines show a higher equality, and the aims of both disciplines are basically to give the students a solid base on the Earth and the history of life. In the case of Spain, however, geological contents appear systematically subordinated to Biology in both extension of development (never above $30 \%$ of the content of the whole subject) and time of teaching. In addition to the short development of contents, these are in all cases left to the final part of the program. This quite often leads to the result of geology chapters being disregarded or explained very superficially. The generally higher proportion of biologists with respect to geologists among the teaching staff in secondary schools does not help to ameliorate the situation. On the other hand, the virtual disappearance of the subject Geology in the last year of the upper cycle $\left(2^{\text {nd }}\right.$ year of Bachillerato $)$ due to lack of motivation after this matter being excluded from the Selectivity proofs to the University, and its substitution by a more general subject of Environmental Sciences reveals the scarce appreciation (and lack of knowledge) of Academic and political authorities for Earth Sciences. This probably has its origin in the erroneous social belief that identifies the field of knowledge of Earth sciences with Biosphere, natural life and environmental problems. 


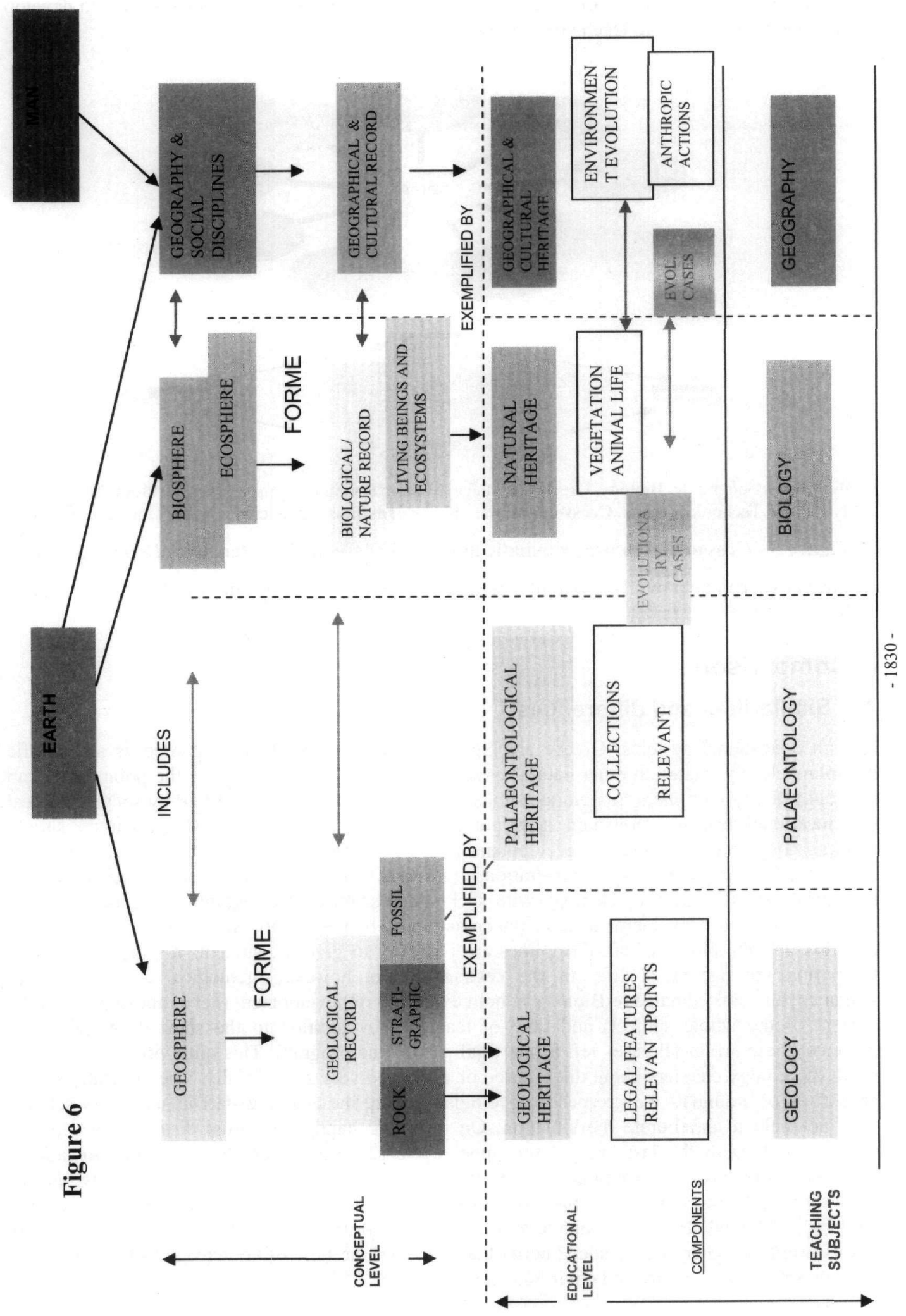




\subsection{The conceptual setting of Geological Sciences}

However, this erroneous identification of the subject of study of these scientific disciplines is no longer justifiable. Actually, although closely related with Natural and Environmental sciences, Geology, and all Earth Sciences disciplines, are not a part of them (Fig. 6). The actual subject of knowledge of Geology is the Geological Record, and this has a separate body of knowledge from "natural" or biological components of the biosphere. On the other hand, although approaches to environmental problems and processes may respond basically to the same factors in the past and present day environments, the methodological process in Geology for the reconstruction of past environments is entirely different. Although Geology may use some uniformitarian principles as a tool for geological interpretation of the past and to reconstruct the History of Earth, it should not be forgotten that the methodological approach in Geology is based on the observation, the empirical testing and the logical interpretation of the Geological Record, including rock, stratigraphic, and fossil record. Therefore, Geology stands as a separate scientific discipline from Natural (biological) and Environmental sciences both from the empirical field of evidence (the database) and the point of view and methodological process of work and interpretation. Rather unlike to what it is usually assumed, considering Geology and geological reconstruction of the History of Earth as a blind translation to the past of present day processes (the "present as a key to the past") the situation is frequently the opposite. Many biological and environmental problems, as well as predictions on the future of climatic change, Earth glaciations, geological risks and catastrophic events, as well as consequences on life of the biosphere alteration (e.g. biological extinctions, ecosystem evolution and species renewal, etc.) are finding a clear approach from the knowledge of past processes and events as interpreted from the geological and from the fossil record. This opposite approach to Earth processes and their consequences on human populations puts forward the Geology as an outstanding scientific discipline with an enormous potential to face and solve environmental problems (i.e. "the past as a key to the present" and as a tool to future predictions).

It is concluded that, despite Geology being only tangentially, taught as an independent subject in Spain and Greece, a pedagogical approach on the values of Geological Heritage, in connection with other disciplines would supply a more interdisciplinary approach, which could be more effective for a sustainable Education.

\section{Conclusions}

The growing decrease of the ratio of Geology in relation with other near nature disciplines in Secondary teaching, as well as its exclusion from access proofs to University (in Spain) to total disappearance in high cycle of Secondary Teaching (in Greece) will clearly bring highly negative consequences to the university background and future research and knowledge of Earth.

The inclusion of Geology within other "twin" or conceptually close subjects, such as Biology, Environmental sciences, or Geography, besides conceptually unjustified, means the actual subordination of Geology, which deals on Earth and Geosphere, to other separate disciplines, dealing on separate subjects of knowledge (Biosphere for Biology; Earth in relation to Man, and human impact on Earth for Geography and Environmental sciences). This subordination has produced a disbalance in teaching, both in the share of text for the different matters, the conceptual accuracy of Geology explained, and the appropriateness of teaching staff.

\section{Acknowledgements}

This paper is a contribution to research projects: Post doctorate research project 2000-01 from State Scholarship Foundation, Greece and CGL 2004/ 02694/BTE (MEC-CSIC), Spain. The authors wish to express their warm thanks to Drs Amelia Calonge and $\mathrm{M}^{\mathrm{a}}$ Dolores López-Carrillo 
for their collaboration with the making of Table 2 and 3 and numerous discussions on the text (Spanish part).

\section{References}

Calonge, A., López-Carrillo, Ma D., and Meléndez, G., (in litt.). The palaeontological heritage in the educational texts from the last grade of the obligatory secondary teaching (ESO) in Spain, Proc. Int. Sym. ProGeo, Geol. Heritage, Braga, Sept. 2005. (in press)

Delvene, G., Meléndez, G., and Menéndez, S., 2006. Colecciones de invertebrados jurásicos en el Museo Geominero (IGME), Reunión Com. Patrimonio SGE., Asturias (MUJA), Junio 2006. Vol. Abstracts, 2p.

Fermeli, G., 2004. Geological-geomorphological heritage, Theory and Praxis-A pedagogical tool for teaching and evaluation of Geology-Georgraphy lesson and Environmental Education, Post Doctorate research, National and Kapodistrian university of Athens, 490pp. (in Greek with English abstract)

Fermeli, G., and Koutsouveli, An. (in litt.) "Geological and Cultural heritage, a dynamic relationship". The case study of the pedagogical geotope "Ancient cave's quarry on Pentelikon mountain- Attica, Greece" and its relationship with the Acropolis of Athens, Proc. Int. Sym. ProGeo, Geol. Heritage, Braga, Sept. 2005 (in press).

Fermeli, G., Marcopoulou-Diacantoni, An., (2004) "Geosciences in the curricula and students books in Secondary education in Greece". Proc. 10th Int. Congr., 2004. Thessaloniki, Greece, Bull. Geol. Soc. Greece, XXXVI, 10. (in Greek with English abstract)

Governmental Paper, 1996-2003. 241/v. A'/ 20-9-96, 1366/v.B'/18-10-2001, 1375 /v.B'/18-102001, 303/v. B'/ 13-3-2003, 304/v. B'/13-3-2003, 1196/v. B'/26-8-2003. (in Greek)

López-Carrillo, Ma D., Calonge, A., and Meléndez, G., 2006. El Patrimonio paleontológico en la enseñanza Secundaria: Problemática y sugerencias, Proc. XX Jornadas Paleontología, SEP. (A. Calonge, R. Gozalo, M.V. Pardo eds.) Alcalá de Henares. Univ. Alcalá, Oct. 2004, 10p.

López-Carrillo, Ma D., Calonge, A., and Meléndez, G., (in litt.) The palaeontological heritage in secondary school educational texts: problems and suggestions, Proc. Int. Sym. ProGeo, Geol Heritage, Braga, Sept. 2005. (in press)

Meléndez, G., Fermeli, G., and Koutsouveli, A., 2006a. Teaching Geology and geological heritage in secondary schools: similar approaches in spanish and greek schools, ProGeo symposium: «Safeguarding our Geological Heritage». Sept 2006, Kiev and Kamianets-Podil'sky, Ukraine. Abstracts vol., 11-12.

Meléndez, G., Ramajo, J., and Bello, J., 2006b. El Patrimonio paleontológico de Andorra: Yacimientos de invertebrados jurásicos de Sierra de Arcos, Revista del CELAN, 4, Andorra.

Meléndez, G., Ramajo, J., Bello, J., and Soria, M., 2006c. El patrimonio paleontológico de la Cordillera Ibérica nororiental: yacimientos de invertebrados jurásicos en los parques culturales del Río Martín y Maestrazgo (prov. Teruel), Proc. Reunión Com. Patrimonio $S G E$. Asturias (MUJA), Junio 2006. Vol. Abstracts, 2p. 